\title{
EFEKTIVITAS MODEL PROBLEM BASED LEARNING BERSASIS METAKOGNITIF TERHADAP KEMAMPUAN BERPIKIR KRITIS MATEMATIS
}

\author{
Muhammad Habib Ramadhani ${ }^{1}$, Caswita ${ }^{2}$, Een Yayah Haenilah ${ }^{3}$ \\ ${ }^{1,2,3}$ Universitas Lampung, Jl. Prof. Dr. Ir Sumantri Brojonegoro, Lampung \\ muhammadhabibramadhani@gmail.com
}

\begin{abstract}
This research is based on the low mathematical critical thinking skills of junior high school students. This study aims to determine the effectiveness of the metacognitive-based problem-based learning model in improving students' mathematical critical thinking skills. This research is a quasi experimental research with pre test and post test control group design. The research subjects were students of class VIII junior high school in Metro City which consisted of an experimental class and a control class. The data collection technique used a test technique in the form of 5 essay questions. The instrument used has met the feasible criteria based on validity, reliability, difference power, and difficulty index. Data analysis using t-test data n-gain. Based on calculations using SPSS 21, the conclusion is that the metacognitive-based problem-based learning model is effective in improving students' critical thinking skills.
\end{abstract}

Keywords: Problem-Based Learning Learning, Metacognitive, Critical Thinking Skills.

\begin{abstract}
Abstrak
Penelitian ini didasari masih rendahnya kemampuan berpikir kritis matematis siswa SMP. Penelitian ini bertujuan untuk mengetahui efektivitas model problem based learning berbasis metakognitif dalam meningkatkan kemampuan berpikir kritis matematis siswa. Penelitian ini merupakan penelitian quasi eksperimental dengan pre test and post test control group design. Subjek penelitian adalah siswa kelas VIII SMP di kota Metro yang terdiri dari kelas eksperimen dan kelas kontrol. Teknik pengumpulan data menggunakan teknik tes berupa 5 soal essay. Instrumen yang digunakan telah memenuhi kriteria layak berdasarkan validitas, reliabilitas, daya beda, dan indeks kesukaran. Analisis data menggunakan uji-t data ngain. Berdasarkan perhitungan menggunakan SPSS 21 diperoleh kesimpulan bahwa model problem based learning berbasis metakognitif efektif dalam meningkatkan kemampuan berpikir kritis siswa.
\end{abstract}

Kata kunci: Problem Based Learning, Metakognitif, Berpikir Kritis.

\section{PENDAHULUAN}

Pendidikan memiliki peranan yang sangat penting dalam meningkatkan kualitas sumber daya manusia yang berkualitas dan dapat berkompetensi di era perkembangan zaman seperti saat ini. Apabila pendidikan dalam negara baik, maka akan berpengaruh terhadap kemajuan dalam ilmu pengetahuan dan teknologi suatu negara. Kenyataan tersebut menjadi tantangan dalam dunia pendidikan. Pendidikan yang baik adalah pendidikan yang mampu mengembangkan keterampilan siswa. Salah satu harapan kurikulum 2013 yang ingin dicapai adalah kemampuan berpikir kritis, khususnya pada mata pelajaran matematika di tingkat SMP. Sehingga peningkatan kemampuan berpikir kritis matematis perlu menjadi suatu hal yang harus diperhatikan.

Berpikir kritis merupakan salah satu dari kemampuan berpikir tingkat tinggi (Novtiar \& Aripin, 2017:120). Sementara itu Abdullah (2013: 66) menambahkan bahwa berpikir kritis merupakan keterampilan untuk memperoleh keputusan-keputusan yang masuk akal (Abdullah, 2013). Berpikir 
Efektivitas Model Problem Based Learning Bersasis Metakognitif Terhadap Kemampuan Berpikir Kritis Matematis, Muhammad Habib Ramadhani, Caswita, Een Yayah Haenilah

kritis merupakan proses dalam memperoleh suatu pengetahuan secara hati-hati, mempertimbangkan terlebih dahulu menggunakan penalaran sebelum menerima pendapat, sehingga memperoleh kesimpulan yang terpercaya dan bisa dipertanggungjawabkan. Berdasarkan beberapa pendapat tentang definisi berpikir krtis tersebut, maka dapat disimpulkan bahwa berpikir kritis merupakan kemampuan seseorang dalam menyampaikan suatu informasi dengan penuh keyakinan berdasarkan infrormasi yang diperoleh dari sumber-sumber yang benar.

Adapun indikator kemampuan berpikir kritis menurut Ennis dalam (Yusuf, 2018) antara lain: a) Elementary clarification, yaitu memberikan penjelasan sederhana; b) Basic support, yaitu membangun keterampilan dasar; c) Inferensi, yaitu menyimpulkan; d) advanced clarification, yaitu membuat penjelasan lanjut; e) Strategies and tactics, yaitu mengatur strategi dan taktik

Berdasarkan bahasan tersebut dapat disimpulkan bahwa kemampuan berpikir kritis diperlukan. Hal tersebut untuk menyikapi perkembangan zaman sekaligus memenuhi tuntutan kurikulum yang berlaku saat ini. Namun kenyataan yang terjadi di lapangan menunjukkan bahwa keterampilan berpikir kritis matematis belum mendapatkan perhatian serius. Kemampuan berpikir kritis siswa khususnya di SMP relatif belum memuaskan.

Berdasarkan hasil wawancara dan observasi pembelajaran matematika kelas VIII di SMP Kota Metro antara lain: a) Proses pembelajaran yang dilakukan di kelas masih berorientasi pada guru, b) Partisipasi aktif hanya didominasi oleh siswa tertentu, c) Siswa mengalami kesulitan ketika dihadapkan pada soal yang berbeda dengan penjelasan contoh soal, d) Ulangan harian siswa menunjukkan hasil belajar matematika siswa masih relatif tergolong rendah.

Austin menyatakan bahwa matematika memerlukan interaksi, baik interaksi siswa dengan guru, siswa dengan teman sejawat, maupun siswa dengan media, sehingga dapat meningkatkan prestasi belajarnya. Ketika siswa menikmati proses pembelajaran, tentu akan lebih mudah mencapai tujuan pembelajaran yang diharapkan (Anas et al., 2013:261). Proses pembelajaran di dalam kelas perlu dirancang sedemikian rupa dengan model pembelajaran yang efektif dalam meningkatkan kemampuan berpikir kritis matematis.

Problem-based learning dapat menjadi alternatif pembelajaran memperhatikan pola berpikir siswa termasuk kemampuan berpikir kritis siswa. Berdasarkan penelitian yang dilakukan oleh Noer diperoleh kenyatan bahwa Problem-based learning dapat meningkatkan keterampilan berpikir kritis matematis (Noer, 2009:479).

Sujana mendefinisikan Problem Based Lerarning sebagai suatu pembelajaran yang menyajikan berbagai situasi permasalahan autentik yang berfungsi bagi siswa, sehingga dapat digunakan untuk melakukan investigasi dan penelitian (Sujana, 2014:132). Sementara itu, menurut Nafiah dan Suyanto Problem Based Lerarning merupakan pembelajaran berdasarkan teori belajar kontruktivisme, dimana keterampilan berpikir dan memecahkan masalah dapat dikembangkan atas kemauan dari siswa itu sendiri, siswa menemukan, dan memindahkan kekomplekan pengetahuan yang ada (Nafiah \& Suyanto, 2014:130). 
Adapun sintaksis problem based learning yang dimodifikasi dari pendapat Arends dapat dilihat pada tabel 1 berikut ini.

\section{Tabel 1}

Sintak Model Problem Based Learning

\begin{tabular}{|c|c|c|}
\hline No. & Fase & Perilaku Siswa \\
\hline 1 & $\begin{array}{l}\text { Fase } 1 \\
\text { Memberikan orientasi mengenai } \\
\text { permasalahan kepada siswa }\end{array}$ & $\begin{array}{l}\text { Siswa memahami tujuan pembelajaran, } \\
\text { mendeskripsikan berbagai kebutuhan logistik penting } \\
\text { dan termotivasi untuk terlibat dalam kegiatan } \\
\text { menyelesaikan masalah }\end{array}$ \\
\hline 2 & $\begin{array}{l}\text { Fase } 2 \\
\text { Mengorganisasikan Siswa agar } \\
\text { dapat melakukan penelitian }\end{array}$ & $\begin{array}{l}\text { Siswa mendefinisikan dan mengorganisasikan tugas- } \\
\text { tugas belajar terkait permasalahannya dengan bantuan } \\
\text { guru }\end{array}$ \\
\hline 3 & $\begin{array}{l}\text { Fase } 3 \\
\text { Membantu melakukan investigasi } \\
\text { secara mandiri dan kelompok }\end{array}$ & $\begin{array}{l}\text { Siswa terdorong untuk mendapatkan informasi yang } \\
\text { terkaitt, melaksanakan eksperimen, dan mencari } \\
\text { penjelasan dan solusi }\end{array}$ \\
\hline 4 & $\begin{array}{l}\text { Fase } 4 \\
\text { Mengembangkan dan } \\
\text { mempresentasikan artefak/ } \\
\text { exhibit. }\end{array}$ & $\begin{array}{l}\text { Siswa merencanakan dan menyiapkan artefak-artefak } \\
\text { yang tepat, seperti laporan, rekaman video, dan model- } \\
\text { model serta menyampaikannya kepada orang lain } \\
\text { dengan bantuan guru }\end{array}$ \\
\hline 5 & $\begin{array}{l}\text { Fase } 5 \\
\text { Menganalisis dan mengevaluasi } \\
\text { proses-proses dalam mengatasi } \\
\text { masalah }\end{array}$ & $\begin{array}{l}\text { Siswa melakukan refleksi terhadap investigasinya dan } \\
\text { proses-proses yang mereka gunakan dengan bantuan } \\
\text { guru }\end{array}$ \\
\hline
\end{tabular}

(Arends, 2012:411)

Berdasarkan uraian tentang Problem based learning, sehiangga dapat disimpulkan bahwa model Problem based learning menjadi salah satu alternatif model yang dapat diterapkan dalam pembelajaran. Namun bukan berarti model problem based learning dapat diterapkan dalam semua kondisi. Kemampuan siswa juga menjadi pertimbangan dalam keberhasilan pernarapan model problem based learning. Bagi siswa yang memiliki minat belajar yang rendah akan mengalami kendala dalam mengikuti pembelajaran problem based learning. Untuk mengatasi permasalahan tersebut, maka solusinya adalah memberikan stimulus metakognitif pada langkah-langkah kegiatan pembelajaran problem based learning.

Adapun metakognisi merupakan pembentukan kesadaran tentang kognitif sendiri, yaitu bagaimana kognitif bekerja serta bagaimana mengaturnya (Siregar, 2017:4). Sementara itu, Yenti mendefinisikan metakognisi sebagai sebuah kesadaran tentang kemampuan yang dimilikinya, baik kemampuan untuk memahami, mengontrol maupun kemampuan memanipulasi proses-proses kognitif yang mereka miliki (Yenti et al., 2012:170). Hal senada juga diungkapkan oleh Kramarski dan Zoldan dalam Nurasyiyah (2014) bahwa pembelajaran metakognitif merupakan pembelajaran yang menanamkan kesadaran bagaimana merancang, memonitor, serta mengontrol tentang apa yang mereka ketahui dan apa yang diperlukan untuk mengerjakan (Nurasyiyah, 2014:117).

Adapun kegiatan metakognitif menurut Weinert \& Kluwe dalam Iskandar (2014) yaitu: perencanaan, monitoring, dan memeriksa hasil. Sementara itu, kegiatan metakognitif tersebut akan muncul melalui empat situasi, yaitu: (1) siswa diminta untuk menjustifkasi suatu kesimpulan atau 
Efektivitas Model Problem Based Learning Bersasis Metakognitif Terhadap Kemampuan Berpikir Kritis Matematis, Muhammad Habib Ramadhani, Caswita, Een Yayah Haenilah

mempertahankan sanggahan; (2) situasi kognitif dalam mengahadapi suatu masalah membuka peluang untuk merumuskan pertanyaan; (3) siswa diminta untuk membuat kesimpulan, pertimbangan dan keputusan yang benar sehingga diperlukan kehati-hatian dalam memantau dan mengatur proses kognitifnya; dan (4) situasi siswa dalam kegiatan kognitif mengalami kesulitan, misalnya dalam pemecahan masalah (Iskandar 2014:16).

Berdasarkan teori-teori yang telah dikemukakan tersebut maka peneliti tertarik untuk meneliti efektifitas model problem based learning berbasis metakognitif. Model problem based learning berbasis metakognitif merupakan pembelajaran dengan menggunakan model problem based learning yang diintegrasikan kegiatan stimulus metakognitif.

Kegiatan model problem based learning berbasis metakognitif ini dilakukan dengan memberikan masalah kepada siswa. Masalah tersebut harus dipecahkan siswa dengan melibatkan aktivitas keterampilan metakognitif. Adapun aktvitas metakognitif diberikan pada tahap ke-3 dari langkah-langkah moel problem based learning, yaitu pada tahap "Membimbing penyelidikan secara mandiri atau kelompok." Dalam penelitian ini, indikator kegiatan metakognitif yang digunakan meliputi: 1) Eksplorasi dan perencanaan, 2) Penemuan strategi penyelesaian masalah, 3) Monitoring dan evaluasi. Dengan demikian model problem based learning berbasis metakognitif diharapkan dapat meningkatkan kemampuan berpikir kritis siswa

\section{METODE}

Penelitian ini merupakan penelitian quasi eksperimental dengan pre test and post test control group design. Populasi dalam penelitian ini adalah seluruh siswa kelas VIII SMP di salah satu kota Metro. Sampel diambil dengan teknik purposive sampling. Penelitian dilakukan pada kelas VIII B sebagai kelas eksperimen dan VIII C sebai kelas kontrol. Adapun desain pre test dan post test control group design (Fraenkel \& Wallen, 2009:271) sebagai berikut:

\section{Tabel 2}

Desain uji lapangan utama

\begin{tabular}{cccc}
\hline \multirow{2}{*}{ Kelas } & \multicolumn{3}{c}{ Perlakuan } \\
\cline { 2 - 4 } & Pre test & Pembelajaran & Post test \\
\hline Eksperimen & $\mathrm{Y}_{1}$ & Model Problem Based Learning Berbasis Metakognitif & $\mathrm{Y}_{2}$ \\
\hline Kontrol & $\mathrm{Y}_{1}$ & Model Problem Based Learning & $\mathrm{Y}_{2}$ \\
\hline
\end{tabular}

Keterangan:

$\mathrm{Y} 1=$ dilaksanakan pre test pada kelas eksperimen dan kontrol

$\mathrm{Y} 2$ = dilaksanakan post test pada kelas eksperimen dan control

Instrumen tes kemampuan berpikir kritis matematis berupa soal yang terdiri dari 5 soal essay dengan materi bangun ruang sisi datar. Soal tersebut diberikan sebelum pembelajaran (pretest) dan setelah pembelajaran (posttest), baik kelas eksperimen maupun kelas kontrol. Instrumen tes yang digunakan tersebut telah dilakukan uji coba terlebih dahulu di kelas IX untuk mengetahui kelayakan intrumen soal. Berdasarkan uji coba intrumen tes, diperoleh data sebagai berikut: 


\section{Tabel 3}

Rekapitulasi Analisis Data Hasil Uji Coba Soal Tes Kemampuan Berpikir Kritis.

\begin{tabular}{cllcccc}
\hline \multirow{2}{*}{ No. } & \multicolumn{1}{c}{ Uji Coba } & \multicolumn{5}{c}{ Soal No } \\
\cline { 2 - 7 } & \multicolumn{1}{c}{ Soal } & 1 & 2 & 3 & 4 & 5 \\
\hline \multirow{2}{*}{1} & Validitas & 0,78 & 0,77 & 0,85 & 0,79 & 0,80 \\
\cline { 2 - 7 } & Kategori & Tinggi & Tinggi & Tinggi & Tinggi & Tinggi \\
\cline { 2 - 7 } & Kriteria & Valid & Valid & Valid & Valid & Valid \\
\hline 2 & Reliabilitas & & & 0,85 & & \\
\cline { 2 - 7 } & Kategori & 0,396 & 0,4583 & 0,4167 & 0,458 & 0,396 \\
\hline 3 & Daya Pembeda & Cukup & Baik & Baik & Baik & Cukup \\
\cline { 2 - 7 } & Kategori & 0,53 & 0,44 & 0,42 & 0,42 & 0,47 \\
\hline 4 & Indeks Kesukaran & Sedang & Sedang & Sedang & Sedang & Sedang \\
\cline { 2 - 7 } & Kategori & & & & & \\
\hline
\end{tabular}

Berdasarkan Tabel 3, dapat dilihat bahwa validitas soal untuk nomor 1, 2, 3, 4, dan 5 memenuhi kategori tinggi dengan kriteria valid. Sementara itu, untuk reliabilitas memiliki kategori tinggi. Daya pembeda nomor 2, 3, dan memiliki kategori baik, sedangkan nomor 1 dan 5 memiliki kategori cukup. Indeks kesukaran pada nomor 1, 2, 3, 4, dan 5 memiliki kategori sedang. Berdasarkan hasil uji coba tes kemampuan berpikir kritis matematis dapat disimpulkan bahwa Instrumen tes kemampuan berpikir kritis layak atau dapat digunakan dalam penelitian.

Sementara itu, analisis kuantitatif diperoleh melalui hasil tes kemampuan berpikir kritis matematis sebelum pembelajaran (pretest) dan setelah pembelajaran (posttest) pada kelas eksperimen dan kontrol. Data yang diperoleh dari pretest dan postest dianalisis menggunakan uji statistik induktif. Sebelum melakukan analisis uji statistik perlu dilakukan uji prasyarat, yang terdiri dari uji normalitas dan homogenitas. Pengujian dalam penelitian ini menggunakan uji leneve dengan SPSS 21. Kriteria pengujian jika probabilitas Sig. > $a$ dengan $a=0,05$ maka hipotesis nol diterima.

Sedangkan untuk mencari tingkat efektivitas menggunakan indeks N-Gain terhadap nilai pretest dan posttest. Selanjutnya untuk melihat besarnya peningkatan dapat dihitung dengan rumus NGain (g). Rumus N-gain menurut Lestari dan Yudhanegara (2017:235) adalah sebagai berikut:

$$
\mathrm{N}-\text { Gain }=\frac{\text { Skor Postest }- \text { Skor pretest }}{\text { Skor maks }- \text { Skor Pretest }}
$$

Data n-gain tersebut merupakan taraf nilai secara individu, selanjutnya menghitung rata-rata dari data n-gain yang diperoleh untuk mengetahui taraf secara luas. Hasil perhitungan N-Gain diintepretasikan dengan menggunakan kriteria sebagai berikut.

\section{Tabel 4}

Kriteria Nilai $N$-gain

\begin{tabular}{cc}
\hline Nilai N-Gain & Kriteria \\
\hline $0,70-1$ & Tinggi \\
\hline $0,31-0,69$ & Sedang \\
\hline $0-0,30$ & Rendah \\
\hline
\end{tabular}

Sumber : (Lestari and Yudhanegara, 2017:235) 
HASIL

Data hasil penelitian diperoleh dari tes kemampuan berpikir kritis matematis. Berdasarkan uji coba lapangan utama yang telah dilakukan diperoleh data sebagai berikut:

\section{Tabel 5}

Analisis data nilai Pretest

\begin{tabular}{cccc}
\hline Kelas & Sig. (Uji Normalitas) & $\begin{array}{c}\text { Sig. (Uji } \\
\text { Homogenitas) }\end{array}$ & $\begin{array}{c}\text { Uji T } \\
\text { (Sig. 2-tailed) }\end{array}$ \\
\hline Eksperimen & 0,107 & 0,864 & 0,898 \\
\hline Kontrol & 0,137 & 0,86 & 0 \\
\hline
\end{tabular}

Berdasarkan Tabel 7, terlihat bahwa nilai Signifikan uji normalitas dan homogenitas, keduanya memperoleh nilai lebih besar dari 0,05 maka nilai pretest kedua kelas bersifat normal dan homogen. Sementara itu, nilai Signifikan pada Uji T (sig. 2-tailed) sebesar 0,898. Karena lebih dari 0.05, maka dapat disimpulkan bahwa tidak ada perbedaan kemampuan awal berpikir kritis siswa di kelas eksperimen dengan kelas kontrol.

\section{Tabel 6}

Analisis data nilai Posttest

\begin{tabular}{cccc}
\hline Kelas & $\begin{array}{c}\text { Sig. (Uji } \\
\text { Normalitas) }\end{array}$ & $\begin{array}{c}\text { Sig. (Uji } \\
\text { Homogenitas) }\end{array}$ & $\begin{array}{c}\text { Uji T } \\
\text { (Sig. 2-tailed) }\end{array}$ \\
\hline Eksperimen & 0,173 & 0,816 & 0,037 \\
\hline Kontrol & 0,095 & 036 & \\
\hline
\end{tabular}

Berdasarkan Tabel 6 terlihat bahwa nilai Signifikan uji normalitas dan homogenitas, keduanya memperoleh nilai lebih besar dari 0,05 maka nilai posttest kedua kelas bersifat normal dan homogen. Sementara itu, nilai Signifikan pada Uji T (sig. 2-tailed) sebesar 0,037. Karena kurang dari 0.05, maka dapat disimpulkan bahwa terdapat perbedaan kemampuan berpikir kritis yang signifikan antara siswa yang menggunakan model problem based learning berbasis metakognitif dengan siswa yang menggunakan model problem based learning.

Selanjutnya, untuk mengetahui seberapa besar peningkatan kemampuan berpikir kritis, maka dilakukan analisis rata-rata data N-Gain, sehingga diperoleh data sebagi berikut:

\section{Tabel 7}

Indeks N-Gain Kemampuan Berpikir Kritis Siswa

\begin{tabular}{cccc}
\hline Kelompok Penelitian & $\begin{array}{c}\text { Jumlah } \\
\text { Siswa }\end{array}$ & $\begin{array}{c}\text { Rata-rata Indeks } \\
\text { N-Gain }\end{array}$ & Kategori Peningkatan \\
\hline Eksperimen & 25 & 0,75 & Tinggi \\
\hline Kontrol & 28 & 0,69 & Sedang \\
\hline
\end{tabular}

Berdasarkan Tabel 7 terlihat bahwa rata-rata indeks n-gain kemampuan berpikir kritis siswa yang menggunakan model problem based learning berbasis metakognitif lebih tinggi dari pada ratarata indeks n-gain kemampuan berpikir kritis siswa yang menggunakan model problem based learning. Rata-rata ndeks n-gain kelas eksperimen adalah 0,75dengan kategori tinggi, sedangkan rata- 
rata indeks n-gain kelas kontrol adalah 0,69 dengan kategori sedang. Kenyataan tersebut menunjukkan bahwa dalam kondisi tersebut, kualitas peningkatan kemampuan berpikir kritis matematis siswa yang pembelajarannya menggunakan model problem based learning berbasis metakognitif lebih baik daripada siswa yang pembelajarannya menggunakan model problem based learning.

\section{KESIMPULAN}

Berdasarkan hasil penelitian pengembangan dan pembahasan yang telah dikemukakan, maka dapat disimpulkan: 1) Terdapat perbedaan yang signifikan antara kemampuan berpikir kritis matematis siswa yang menggunakan model problem based learning berbasis metakognitif dengan kemampuan berpikir kritis matematis siswa yang menggunakan model problem based learning; 2) Model problem based learning berbasis metakognitif efektif meningkatkan kemampuan berpikir kritis matematis siswa. Model ini memiliki tingkat efektivitas yang tinggi dalam meningkatkan kemampuan berpikir kritis pada materi bangun ruang sisi datar kelas VIII semester 2.

\section{DAFTAR PUSTAKA}

Abdullah, I. H. (2013). Berpikir Kritis Matematik. Jurnal Matematika Dan Pendidikan Matematika, 2(1), 66-75. https://doi.org/10.18860/jt.v0i0.1442

Anas, M., Atmoko, T., \& Suyono. (2013). Eksperimentasi Model pembelajaran Think Pairshare Modifikasi Penentuan Terbimbing Berbantuan Microsoft Power Point pada Pembelajaran Matematika Ditinjau dari Kedisiplinan Belajar. Jurnal Pendidikan, 259-267. http://download.portalgaruda.org/article.php?article=106933\&val=4039

Arends, R. (2012). Learning To Teach, Ninth Edition. Americas. McGraw-Hill Companies Inc. file:///C:/Users/youhe/Downloads/kdoc_o_00042_01.pdf

Fraenkel, J. R., \& Wallen, N. E. (2009). How to Design and Evaluate Research in Education - Seven Edition. In Journal of Visual Languages \& Computing (Seven). McGraw-Hill. Inc. https://www.m-

culture.go.th/mculture_th/download/king9/Glossary_about_HM_King_Bhumibol_Adulyadej's_ Funeral.pdf

Iskandar, S. M. (2014). Pendekatan Keterampilan Metakognitif dalam pembelajaran Sains di Kelas. Erudio Journal of Educational Innovation, 2(2), 13-20. https://doi.org/10.18551/erudio.2-2.3

Lestari, K. E., \& Yudhanegara, M. R. (2017). Penelitian Pendidikan Matematika: Panduan Praktis Menyusun Skripsi, Tesis, dan Laporan Penelitian dengan Pendekatan Kuantitatif, Kualitatif, dan Kombinasi Disertai dengan Model Pembelajaran dan Kemampuan Matematis. PT Refika Aditama.

Nafiah, Y. N., \& Suyanto, W. (2014). Penerapan Model problem Based Learning untuk Meningkatkan Keterampilan Berpikir Kritis dan Hasil Belajar Siswa. Jurnal Pendidikan Vokasi, 4(1), 125-143. https://doi.org/10.21831/jpv.v4i1.2540

Noer, S. H. (2009). Peningkatan Kemampuan Berpikir Kritis Matematis Siswa SMP Melalui 
Efektivitas Model Problem Based Learning Bersasis Metakognitif Terhadap Kemampuan Berpikir Kritis Matematis, Muhammad Habib Ramadhani, Caswita, Een Yayah Haenilah

Pembelajaran Berbasis Masalah. Prosiding Seminar Nasional Matematika Dan Pendidikan Matematika Jurusan Pendidikan Matematika FMIPA UNY, 5 Desember 2009, 473-483.

Novtiar, C., \& Aripin, U. (2017). Meningkatkan Kemampuan Berpikir Kritis Matematis dan Keercayaan Diri Siswa SMP Melalui Pendekatan Open Ended. Prisma, 6(2), 119-131. https://doi.org/10.35194/jp.v6i2.122

Nurasyiyah, D. A. (2014). PEMECAHAN MASALAH MATEMATIK SISWA SMA Desy Ayu Nurasyiyah Universitas Pendidikan Indonesia Kemampuan-kemampuan yang dikembangkan dalam pembelajaran matematika adalah pemahaman, penalaran , koneksi , investigasi , komunikasi , pemecahan masalah ( Suherman. Jmp, 6, 115-125.

Siregar, N. (2017). Pendekatan Metakognitif Berbasis Masalah sebagai Pembelajaran Matematika. REKOGNISI: Jurnal Pendidikan Matematika, 2(2), 1-20.

Sujana, A. (2014). Pendidikan IPA Teori dan Praktik. Rizqi Press.

YENTI, I. N., Afriyani, D., \& Herawati, S. (2012). Pengembangan Rencana Pelaksanaan Pembelajaran (RPP) dan Penampilan Diri Berbasis Metakognisi untuk Statistika Elementer. Ta'dib, 15(2). https://doi.org/10.31958/jt.v15i2.229

Yusuf, O. L. (2018). Desain Soft Skills Pembelajaran Matematika Berbasis Model Problem Based Learning Untuk Meningkatkan Kemampuan Berpikir Kritis Matematis Siswa (Tesis). Universitas Lampung. 